\title{
Morphogenetic and structural characteristics of signal grass in response to liming and defoliation severity ${ }^{1}$
}

\author{
Lilian Elgalise Techio Pereira ${ }^{2}$, Valdo Rodrigues Herling ${ }^{2}$, Junior Cesar Avanzi ${ }^{3}$, Sila Carneiro da Silva ${ }^{4}$
}

\section{ABSTRACT}

The control of soil acidity through liming and the adoption of adequate management are essential to the maintenance of pastures productivity. The morphogenetic and structural characteristics of Urochloa decumbens cv. Basilisk, in canopies with $\left(0.7 \mathrm{t} \mathrm{ha}^{-1}\right.$ and $\left.1.0 \mathrm{tha}^{-1}\right)$ or without liming and subjected to severe or lenient cuttings (stubble corresponding to $40 \%$ or $60 \%$ of the pre-harvest height, respectively), were evaluated throughout regrowth, during late spring and summer. Treatments were distributed in a $3 \times 2$ factorial arrangement, in a completely randomized block design, with 3 replications ( $80 \mathrm{~m}^{2}$ plots). Increased liming rates do not result in benefits to the herbage mass, tiller population density or a faster canopy recovering. The average tiller weight decreases, while the duration of regrowth linearly increases, with increasing liming rates, particularly in late spring. Stem elongation and leaf senescence rates increase and leaf elongation rates decrease from the 15 th day of regrowth, regardless of the liming rates or defoliation severities. Post-harvest heights ranging from $40 \%$ to $60 \%$ of the pre-harvest height showed to be within the tolerance limits to defoliation of $U$. decumbens. The liming rates adopted had only marginal impacts on the morphogenetic characteristics of $U$. decumbens.

KEYWORDS: Urochloa decumbens cv. Basilisk; stem elongation; regrowth dynamics; light interception.

\section{INTRODUCTION}

The physiological and growth processes at plant and population level play a central role in determining how fast the vegetal communities adapt to the grazing management (Silva et al. 2015). Thus, the knowledge about the growth characteristics of

\section{RESUMO}

Características morfogênicas e estruturais de capimbraquiária em resposta a calagem e severidade de corte

O controle da acidez do solo por meio de calagem, aliado à adoção de manejo correto, são fatores essenciais para a manutenção da produtividade de pastagens. Avaliaram-se, ao longo da rebrotação, no final da primavera e verão, as características morfogênicas e estruturais da Urochloa decumbens cv. Basilisk, em dosséis que receberam $\left(0,7 \mathrm{t} \mathrm{ha}^{-1}\right.$ e $\left.1,0 \mathrm{t} \mathrm{ha}^{-1}\right)$ ou não calagem, submetidos a cortes severos ou lenientes (resíduo correspondente a $40 \%$ ou $60 \%$ da altura précorte, respectivamente). Os tratamentos foram distribuídos em arranjo fatorial $3 \times 2$, em delineamento de blocos completos casualizados, com 3 repetições (parcelas de $80 \mathrm{~m}^{2}$ ). O aumento nas doses de calcário não resulta em maior massa de forragem, densidade populacional de perfilhos ou recuperação mais rápida do dossel. O peso médio de perfilhos diminui, enquanto a duração da rebrotação aumenta linearmente, com aumentos nas doses de calcário, particularmente no final da primavera. Aumentos nas taxas de alongamento de colmos e senescência de folhas e diminuição nas taxas de alongamento de folhas ocorrem a partir do $15^{\circ}$ dia de rebrotação, independentemente da quantidade de calcário ou severidade de corte. Severidades de corte variando de $40 \%$ a $60 \%$ da altura pré-corte mostraram-se dentro dos limites de tolerância à desfolhação em U. decumbens. As doses de calcário adotadas tiveram apenas impactos marginais nas características morfogenênicas de $U$. decumbens.

PALAVRAS-CHAVE: Urochloa decumbens cv. Basilisk; alongamento de colmos; dinâmica de rebrotação; interceptação luminosa.

grasses, especially the tropical perennial grasses, is essential for the establishment of effective management strategies, which should be easily and rapidly defined to the canopies, in order to recover the leaf area (Gastal \& Lemaire 2015).

Soil properties, particularly those determining the nutrients availability, also play an important role

1. Manuscript received in Sept./2017 and accepted for publication in Dec./2017 (http://dx.doi.org/10.1590/1983-40632018v4849212).

2. Universidade de São Paulo, Faculdade de Zootecnia e Engenharia de Alimentos, Departamento de Zootecnia, Pirassununga,

São Paulo, SP, Brasil.E-mails: 1techio@usp.br, vrherlin@usp.br.

3. Universidade Federal de Lavras, Departamento de Ciência do Solo, Lavras, MG, Brasil. E-mail: junior.avanzi@dcs.ufla.br.

4. Universidade de São Paulo, Escola Superior de Agricultura "Luiz de Queiroz", Departamento de Zootecnia, Piracicaba, São Paulo, SP, Brasil.E-mail: scdsilva@usp.br. 
in grazed pastures, since they modulate how fast swards recover after grazing (Magalhães et al. 2017). Since most soils in Brazil are naturally acid, liming is considered an essential agronomic practice to maintain pastures productivity and persistence (Oliveira et al. 2003, Costa et al. 2012), increasing the soil base saturation, $\mathrm{pH}$ values and $\mathrm{P}$ availability, and decreasing Al saturation (Raij et al. 1997, Goulding 2016).

Despite the high tolerance of Urochloa decumbens pastures to low soil fertility (Werner et al. 1996, Dias-Filho 2014), the growth patterns throughout the regrowth process related to the adjustments in morphogenetic traits at tiller level and changes in population density and tiller weight in response to liming are poorly understood. This knowledge is essential to understand the mechanisms triggered by this grass species that has preventing the maximization of herbage accumulation and buffered productivity, in response to the increasing liming rates commonly described in the literature (Premazzi \& Mattos 2002, Oliveira et al. 2003).

The defoliation severity is an important component of grazing management affecting the sward recovering, once it determines the residual herbage mass and the remaining leaf area (Pereira et al. 2014, Silva et al. 2015), and the time required for regrowth is normally longer as lower are the post-grazing heights (Ferraro \& Oesterheld 2002). Despite that, a faster sward recovering would be expected, if fertilization practices can supply the nutrients required for the initial sward regrowth. Thus, it was hypothesized that defoliation severities have a lower impact on the morphogenetic traits and tiller population density in Urochloa decumbens, as liming rates increase. On the other hand, a decreased ability to maintain high tiller population density and leaf elongation rates is expected when swards are established on unlimed soils, particularly when associated to severe defoliation. Thus, this study aimed to describe the morphogenetic and structural characteristics of Urochloa decumbens $\mathrm{cv}$. Basilisk throughout regrowth in response to liming rates, when swards are subjected to severe or lenient defoliation (stubble corresponding to $40 \%$ or $60 \%$ of the pre-harvest height, respectively), during late spring and summer.

\section{MATERIAL AND METHODS}

The experiment was carried out at the Universidade de São Paulo, in Pirassununga, São
Paulo state, Brazil $\left(21^{\circ} 36^{\prime} \mathrm{N}, 47^{\circ} 15^{\prime} \mathrm{W}\right.$ and $620 \mathrm{~m}$ a.s.l.). The slope is moderately undulate and the soil classified as an Oxisol (Dystrophic Red Latosol, according to Embrapa 2013). The climate is Cwa (sub-tropical with dry winter) and the average annual rainfall is around $1,395 \mathrm{~mm}$. The average temperatures during the experimental period (October 2015 to March 2016) ranged $18.9-25.0{ }^{\circ} \mathrm{C}$. The average montly rainfall during late spring (October to December 2015) and summer (January to March 2016) were, respectively, $203.4 \mathrm{~mm}$ and $259.2 \mathrm{~mm}$.

The experimental treatments resulted from the combination of three liming rates [ $\mathrm{C} 0.0$ (no limestone applied); $\mathrm{C} 0.7$ (liming rate equivalent to $0.7 \mathrm{t} \mathrm{ha}^{-1}$ ); and $\mathrm{C} 1.0$ (liming rate equivalent to $\left.\left.1.0 \mathrm{t} \mathrm{ha}^{-1}\right)\right]$ and two defoliation severities, in which the stubble corresponded to $40 \%$ (R40, severe) or $60 \%$ (R60, lenient) of the pre-harvest height. The experimental area comprised 18 paddocks $\left(80 \mathrm{~m}^{2}\right)$ distributed in three blocks, according to the soil slope. The experimental design was a randomized complete block and treatments were distributed in a $3 \times 2$ factorial arrangement, with three replications.

The soil samples were collected in January 2015, and the average soil chemical characteristics (0-20 cm layer) in the paddocks attributed to the treatments $\mathrm{C} 0.0, \mathrm{C} 0.7$ and $\mathrm{C} 1.0$ were, respectively: $\mathrm{pH}$ $\left(\mathrm{CaCl}_{2}\right): 4.8,5.1$ and 5.3; organic matter $=20.5 \mathrm{~g} \mathrm{~kg}^{-1}$, $23.0 \mathrm{~g} \mathrm{~kg}^{-1}$ and $23.3 \mathrm{~g} \mathrm{~kg}^{-1} ; \mathrm{P}$ (resin) $=5.7 \mathrm{mg} \mathrm{dm}^{-3}$, $7.3 \mathrm{mg} \mathrm{dm}^{-3}$ and $11.2 \mathrm{mg} \mathrm{dm}^{-3} ; \mathrm{Ca}=8.8 \mathrm{mmol}_{\mathrm{c}} \mathrm{dm}^{-3}$, $12.7 \mathrm{mmol}_{\mathrm{c}} \mathrm{dm}^{-3}$ and $19.3 \mathrm{mmol}_{\mathrm{c}} \mathrm{dm}^{-3} ; \mathrm{Mg}^{\mathrm{c}}=$ $4.3 \mathrm{mmol}_{\mathrm{c}} \mathrm{dm}^{-3}, 5.5 \mathrm{mmol}_{\mathrm{c}} \mathrm{dm}^{-3}$ and $6.2 \mathrm{mmol}_{\mathrm{c}} \mathrm{dm}^{-3}$; $\mathrm{K}=2.6 \mathrm{mmol} \mathrm{dm}^{-3}, 2.5 \mathrm{mmol} \mathrm{dm}^{-3}$ and $2.3 \mathrm{mmol} \mathrm{dm}^{-3}$; $\mathrm{S}=8.5 \mathrm{mg} \mathrm{dm}^{-3}, 22.0 \mathrm{mg} \mathrm{dm}^{-3}$ and $25.0 \mathrm{mg} \mathrm{dm}^{-3}$; $\mathrm{H}+\mathrm{Al}=24.5 \mathrm{mmol}_{\mathrm{c}} \mathrm{dm}^{-3}, 24.2 \mathrm{mmol}_{\mathrm{c}} \mathrm{dm}^{-3}$ and $24.3 \mathrm{mmol}_{\mathrm{c}} \mathrm{dm}^{-3}$; sum of bases $=15.8 \mathrm{mmol}_{\mathrm{c}} \mathrm{dm}^{-3}$, $20.6 \mathrm{mmol} \mathrm{dm}^{-3}$ and $27.8 \mathrm{mmol}_{\mathrm{c}} \mathrm{dm}^{-3}$; cation exchange capacity $=40.5 \mathrm{mmol}_{\mathrm{c}} \mathrm{dm}^{-3}, 44.8 \mathrm{mmol}_{\mathrm{c}} \mathrm{dm}^{-3}$ and $52.0 \mathrm{mmol}_{\mathrm{c}} \mathrm{dm}^{-3}$; soil base saturation $=39.1 \%$, $45.9 \%$ and $51.2 \%$.

The liming rates applied corresponded to the elevation of the soil base saturation to $50 \%$ and $65 \%$, in the treatments $\mathrm{C} 0.7$ and $\mathrm{C} 1.0$, respectively. Dolomitic limestone (89\% TNRP) was applied after mowing ( $5 \mathrm{~cm}$ above the ground) without incorporation, in April 2015. The annual fertilization was equivalent to $106.5 \mathrm{~kg} \mathrm{ha}^{-1}$ of N, $52.5 \mathrm{~kg} \mathrm{ha}^{-1}$ of $\mathrm{P}_{2} \mathrm{O}_{5}$ and $35 \mathrm{~kg} \mathrm{ha}^{-1}$ of $\mathrm{K}_{2} \mathrm{O}$ (Raij et al. 1997), splitted in three applications: in November 2015, by applying the equivalent to $17.5 \mathrm{~kg} \mathrm{ha}^{-1}$ of $\mathrm{N}, 52.5 \mathrm{~kg} \mathrm{ha}^{-1}$ of $\mathrm{P}_{2} \mathrm{O}_{5}$ 
and $35 \mathrm{~kg} \mathrm{ha}^{-1}$ of $\mathrm{K}_{2} \mathrm{O}$ (formulated fertilizer 5-15-10); and on 05 December 2015 and 26 January 2016, with the equivalent to $49.5 \mathrm{~kg} \mathrm{ha}^{-1}$ and $39.5 \mathrm{~kg} \mathrm{ha}^{-1}$ of $\mathrm{N}$, using ammonium nitrate ( $33 \%$ of $\mathrm{N})$.

The Urochloa decumbens cv. Basilisk swards were mowed at $5 \mathrm{~cm}$, in April 2015, after which the monitoring of the experimental conditions started. The criterion to define the pre-harvest condition was the moment in which the swards intercepted 0.95 of the incoming photosynthetically active solar radiation $\left(\mathrm{LI}_{0.95}\right)$, following recommendations by Silva et al. (2015). Plots were defoliated using a costal mower. The experimental period started in November 2015, and measurements were carried out up to March 2016, comprising two seasons: late spring (November and December) and summer (January to March).

Canopy light interception was monitored during regrowth, using a LAI 2000 canopy analyzer (LI-COR, Lincoln, Nebraska, USA). Readings were taken from two sampling areas, in which one reading was taken above the canopy and five at the ground level. Sward height was monitored throughout each regrowth cycle through 20 systematic readings along four transect lines, using a meter stick graduated in $\mathrm{cm}$. To determine the herbage mass, two samples were cut at the ground level using a $0.50 \mathrm{~m}$ x $0.50 \mathrm{~m}$ $\left(0.25 \mathrm{~m}^{2}\right)$ metallic frame. After cutting, samples were weighed and separated into two sub-samples: one for the determination of the dry matter content and the other for manual dissection into the leaf (leaf laminae), stem (leaf sheath + stem) and dead material.

The tiller population density (tiller $\mathrm{m}^{-2}$ ) was determined by counting the number of tillers within two metallic frames $(0.5 \mathrm{~m} \times 0.5 \mathrm{~m})$. Tiller weight $\left(\mathrm{g} \mathrm{tiller}^{-1}\right.$ ) was acessed from 20 tillers randomly collected per paddock, which were dried in a forceddraft oven, at $65^{\circ} \mathrm{C}$, until reaching a constant mass. Procedures to determine the tiller population density and tiller weight were performed at three stages during regrowth: post-harvest, intermediate phase of regrowth and pre-harvest. Morphogenetic traits were assessed in five tillers per experimental unit. Tillers were monitored every 3 days throughout the regrowth period. Leaves were classified as expanding (the ligule was not exposed and the lamina length was measured from the ligule of the last expanded leaf), expanded (the ligule was visible and/or there was no variation in the lamina length between two consecutive measurements) or senescing (the lamina showed signs of being endangered by senescence).
Stem length was measured as the distance between the ground level for basal tillers, or from the insertion point for axillary tillers, up to the ligule of the last expanded leaf. The variables were calculated as described by Pereira et al. (2014) to obtain: leaf elongation $\left(\mathrm{cm}\right.$ tiller $^{-1}$ day $\left.^{-1}\right)$, leaf appearance (tiller ${ }^{-1}$ day $\left.^{-1}\right)$, leaf senescence $\left(\mathrm{cm}\right.$ tiller ${ }^{-1}$ day $\left.^{-1}\right)$ and stem elongation $\left(\mathrm{cm}^{-1}\right.$ tiller $^{-1}$ day $\left.^{-1}\right)$ rates.

Variance analysis was performed using the Mixed Procedure $\left(\mathrm{SAS}^{\circledR}\right.$, version 8.2). The variance analysis regarding light interception, herbage mass and sward height were carried out separately for the post and pre-harvest stages, considering the liming rates, defoliation severities, season of the year and their interactions as fixed factors and blocks as a random factor. The season of the year was considered a repeated measure, and $\mathrm{VC}$ was the covariance matrix used. The variance analysis for tiller population density and tiller weight considered the liming rates, defoliation severities, regrowth phase (post-harvest, intermediate and pre-harvest), season of the year and their interactions as fixed factors and blocks as a random factor. The season of the year and the regrowth phase were considered repeated measures, and UN@CS was the covariance matrix used. The variance analysis to the morphogenetic traits considered the liming rates, defoliation severities, regrowth phase (5-day intervals), season of the year and their interactions as fixed factors and blocks as a random factor. The season of the year and the regrowth phase were treated as repeated measures, and UN@CS was the covariance matrix used for all variables.

For all variables, the correction for degrees of freedom was made by the Kenward \& Roger (1997) method $(\mathrm{DDFM}=\mathrm{KR})$. When appropriate, means were calculated using the 'LSMEANS', comparisons were made using the 'PDIFF $=$ ALL' option and significant differences were declared when $\mathrm{p}<0.05$. When significant effects were detected for liming rates, the relationships were quantified using linear regression (PROC REG of the $\mathrm{SAS}^{\circledR}$, version 8.2) and evaluated for goodness of fit $\left(\mathrm{R}^{2}\right)$ and significance. When significant effects of liming rates or regrowth phase were detected for the variables leaf elongation, leaf appearance, leaf senescence and stem elongation rates, the relationships were studied by testing models up to the third order (PROC REG of the SAS ${ }^{\circledR}$, version 8.2) and evaluated for goodness of fit $\left(\mathrm{R}^{2}\right)$ and significance. 


\section{RESULTS AND DISCUSSION}

Light interception during the post-harvest stage varied only with season $(p<0.0001)$ and higher values were observed during summer $(80.1 \pm$ $1.12 \%)$, if compared to late spring $(68.6 \pm 1.12 \%)$. The average post-harvest heights related to the defoliation severities R40 and R60 corresponded to $14.7 \pm 0.66 \mathrm{~cm}$ and $19.7 \pm 0.66 \mathrm{~cm}$ (Table 1), and the pre-harvest heights varied with the interaction season $\mathrm{x}$ defoliation severity $(\mathrm{p}=0.031)$. Similar values for the pre-harvest height between R40 (35.0 \pm $1.83 \mathrm{~cm})$ and R60 $(32.6 \pm 1.83 \mathrm{~cm})$ were observed during late spring. During summer, higher values were registered in R60 (38.3 $\pm 1.83 \mathrm{~cm})$, if compared to $\mathrm{R} 40(33.1 \pm 1.83 \mathrm{~cm})$. Increased liming rates did not result in benefits to the herbage mass or faster sward recovering. There were no effects of the liming rates, defoliation severities and season of the year, or significant interactions among these factors $(p>0.05)$, to the herbage mass at the post- or pre-harvest stage. The duration of regrowth (DR, days) varied with the liming rates $(\mathrm{p}=0.0052)$ and with the interaction season $x$ defoliation severities $(p=0.0228)$. The duration of regrowth linearly increased as liming rates $(\mathrm{LR})$ increased $\left[\mathrm{DR}=16.2+0.17 *(\mathrm{LR}) ; \mathrm{R}^{2}=\right.$ $0.15 ; p=0.0183$ ]. During late spring, the duration of regrowth was similar between defoliation severities $(23.2 \pm 1.27$ days in $\mathrm{R} 40$ and $22.0 \pm 1.27$ days in $\mathrm{R} 60)$, but longer in $\mathrm{R} 40$ (30.5 \pm 1.27 days) than R60 (23.1 \pm 1.27 days) during summer.

Urochloa decumbens is a tropical perennial grass widely used in grazed systems in Brazil, being considered one of the grass species most well adapted to low soil $\mathrm{pH}$ and tolerant to high levels of $\mathrm{Al}$ saturation (Valle et al. 2010). Thus, it is classified as a species with low demand in soil fertility, if compared with other species of the genera (Raij et al. 1997). According to Aerts (1999), the natural selection in nutrient-poor habitats does not necessarily result in plants with a high competitive ability for nutrients and high growth rates, but rather on traits which reduce nutrient losses, such as low tissue nutrient concentrations, slow tissue turnover rates and high nutrient resorption efficiency. All those responses typically comprise resource conservation strategies and seem to be predominant in $U$. decumbens, thus preventing the maximization of sward growth as liming rates increase. The annual fertilization levels adopted in this study probably favored the maintenance of stable growth rates, regardless of the liming rates adopted. Besides, the absence of response to increased liming rates, in terms of herbage mass, was previously reported in the literature (Premazzi \& Mattos 2002, Oliveira et al. 2003).

The persistency of tropical perennial grasses is ensured by the constant renewal of the tiller population throughout the growth season, in a process known as tillering. The proportion of basal and aerial tillers comprising the total tiller population, as well as the seasonal patterns of tillering, are species-dependent, but are also affected by the defoliation regime. Portela et al. (2011) showed that $U$. decumbens cv. Basilisk is able to maintain a similar total tiller population density throughout the growth season, when canopies are subjected to frequent grazing $\left(\mathrm{LI}_{0.95}\right)$ or long regrowth periods (less frequent grazing regime), combined with severe (stubble of $5 \mathrm{~cm}$ ) or less severe (stubble of $10 \mathrm{~cm}$ ) grazing. This plasticity to adjust the total tiller population density facing the grazing strategies imposed (Pedreira et al. 2017) was reached by changing the proportion of basal and aerial tillers in the population (Portela et al. 2011). Similarly to those results, the total tiller population density was not affected by liming rates or defoliation severity, and varied only with the regrowth phase $(\mathrm{p}=0.0028)$. The lower tiller population density was registered in the post-harvest stage (787.6 \pm

Table 1. Sward responses at post- and pre-harvest stages in Urochloa decumbens cv. Basilisk subjected to two defoliation severities.

\begin{tabular}{lrrrrrrrr}
\hline \multirow{2}{*}{ Canopy response* } & \multicolumn{4}{c}{ Post-harvest } & \multicolumn{4}{c}{ Pre-harvest } \\
\cline { 2 - 10 } & R40† & \multicolumn{1}{c}{ R60 } & SEM & SED $\S$ & \multicolumn{1}{c}{ R40 } & R60 & SEM & SED \\
\hline LI (\%) & 72.8 & 75.8 & \pm 1.12 & 1.56 & 95.0 & 95.7 & \pm 0.15 & 0.211 \\
CH (cm) & 14.7 & 19.7 & \pm 0.66 & 0.93 & 34.1 & 35.4 & \pm 1.41 & 1.650 \\
HM (kg ha ${ }^{-1}$ of DM) & $3,880.0$ & $4,511.0$ & \pm 256.60 & 362.80 & $4,581.0$ & $5,480.0$ & \pm 309.10 & 437.200 \\
DR (days) & - & - & - & - & 26.9 & 22.5 & \pm 0.90 & 1.280 \\
\hline
\end{tabular}

* LI: light interception; CH: canopy height; HM: herbage mass; DM: dry matter; DR: duration of the regrowth period; $\uparrow$ R40 and R60: stubble of $40 \%$ or $60 \%$ of the pre-harvest height, respectively; $\$$ : standard error of the mean; §: standard error of the difference for mean comparisons across defoliation severities. 
38.03 tillers $\mathrm{m}^{-2}$ ), but increased aproximately $18 \%$ from the post- to the intermediate phase of regrowth $\left(932.6 \pm 38.03\right.$ tillers $\left.\mathrm{m}^{-2}\right)$. Non-significant differences were observed between the intermediate and the pre-harvest stage $\left(1,003.2 \pm 38.03\right.$ tillers $\left.\mathrm{m}^{-2}\right)$. The tiller weight $\left(\mathrm{g} \mathrm{tiller}^{-1}\right)$ varied with the interactions regrowth phase $x$ season $(p=0.0357)$, liming rates $x$ season $(\mathrm{p}=0.0174)$ and regrowth phase $\mathrm{x}$ defoliation severity $x$ liming rates $(p=0.0354)$. There were no significant differences in tiller weight between the regrowth phases during late spring. During summer, tiller weight was similar from the post-harvest to the intermediate phase of regrowth, but increased aproximately $28 \%$ at the pre-harvest (Figure 1A). Comparing seasons, significant differences in tiller weight were registered only in $\mathrm{C} 0.0$, with higher values during late spring, relatively to summer. The tiller weight decreased linearly as liming rates increased during late spring (Figure 1B), but the linear regression equation was not statistically significant during summer $(\mathrm{p}>0.05)$.

At the post-harvest and intermediate stage of regrowth, significant linear regression equations were adjusted only in R60, showing that the tiller weight decreased linearly as liming rates increased (Figure 2). At pre-harvest, the tiller weight decreased linearly as liming rates increased in R40, but the linear regression equation was not statistically significant in R60. A significant difference in tiller weight between the defoliation severities was observed only in the post-harvest phase, in which a higher tiller weight was registered in R60, if compared to R40.

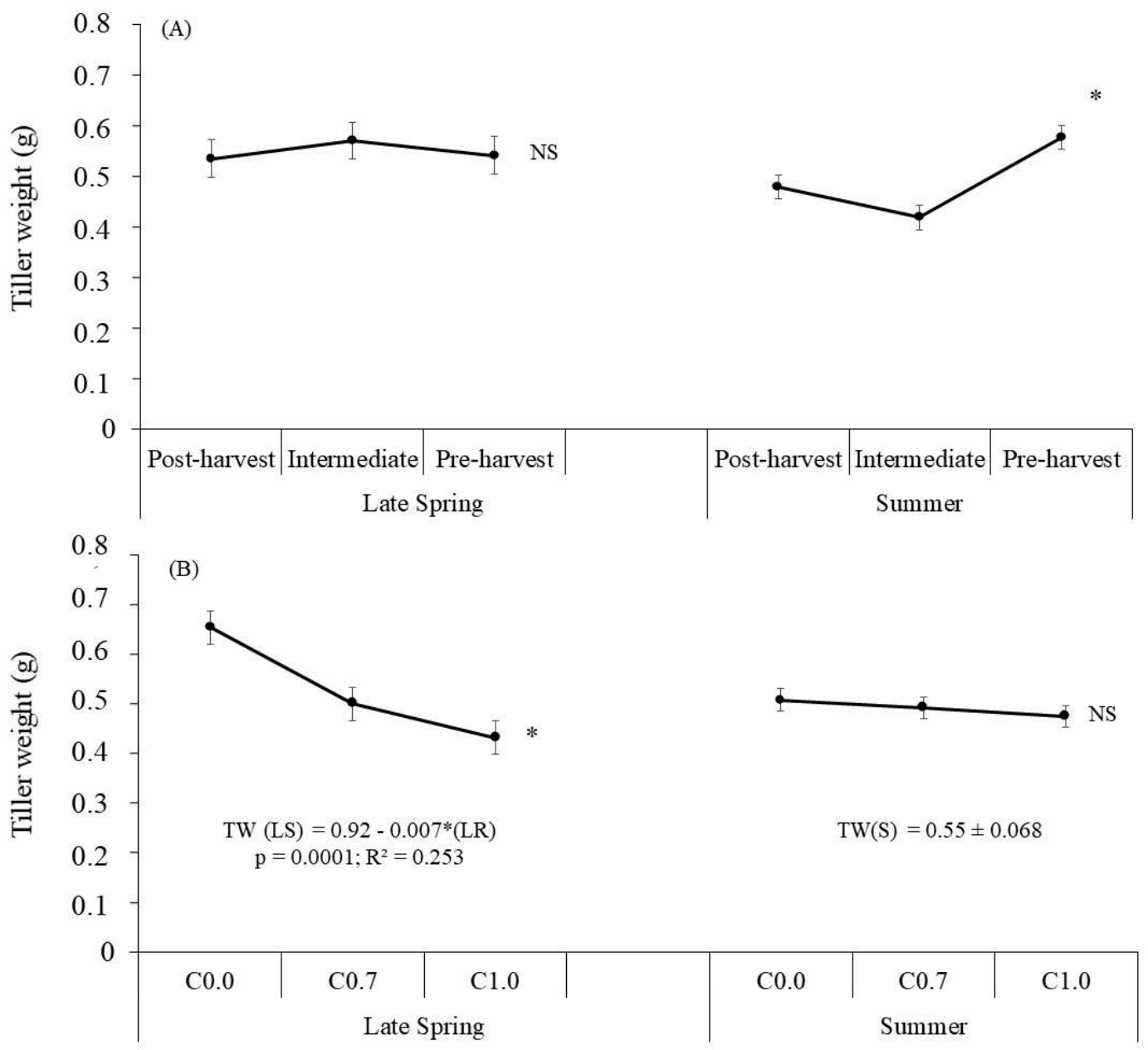

Figure 1. Tiller weight (TW) of Urochloa decumbens cv. Basilisk, according to the interactions regrowth phase $\mathrm{x}$ season (A) and liming rates (LR) x season (B). For each season, asterisks indicate significant differences between regrowth phases (A) or liming rates (B); NS indicates non-significant differences between regrowth phases (A) or liming rates (B); C0.0, C0.7 and $\mathrm{C} 1.0$ represent swards without liming, or liming rates equivalent to $0.7 \mathrm{t} \mathrm{ha}^{-1}$ or $1.0 \mathrm{t} \mathrm{ha}^{-1}$ of limestone, respectively. Bars represent the standard error of the means. 


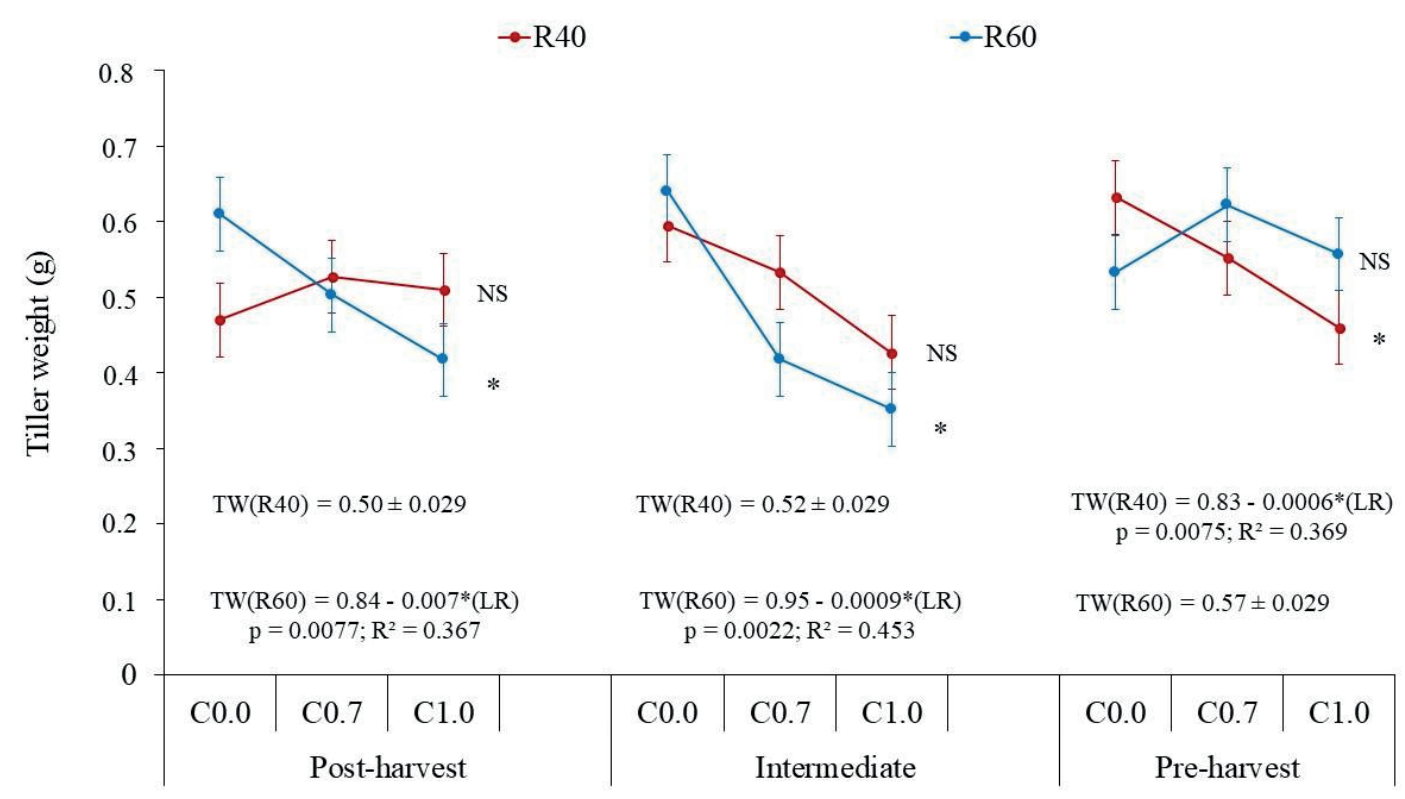

Figure 2. Tiller weight (TW) of Urochloa decumbens cv. Basilisk, according to the interaction regrowth phase $\mathrm{x}$ liming rates (LR) $\mathrm{x}$ defoliation severities. For each regrowth phase, asterisks indicate significant differences between liming rates; NS indicates non-significant differences between regrowth phases; $\mathrm{C} 0.0, \mathrm{C} 0.7$ and $\mathrm{C} 1.0$ represent swards without liming, or liming rates equivalent to $0.7 \mathrm{t} \mathrm{ha}^{-1}$ or $1.0 \mathrm{t} \mathrm{ha}^{-1}$ of limestone, respectively; R40 and R60 correspond to stubble of $40 \%$ or $60 \%$ of the pre-harvest height, respectively.

A great part of the low demand in soil nutrients of $U$. decumbens is related to the ability to maintain an effective association with arbuscular mycorrhizal fungi, which increases the soil volume explored by roots and the absorption of nutrients, particularly $\mathrm{P}$ and $\mathrm{N}$, as well as micronutrients such as $\mathrm{Zn}$ and $\mathrm{Cu}$ (George et al. 1995, Clark \& Zeto 2000). This association plays a crucial role for the establishment and persistency of $U$. decumbens pastures in nutrientdeficient acidic soils (Siqueira et al. 1990, Motta et al. 2017). Besides, Carrenho et al. (2007) observed that liming decreased the root colonization by arbuscular mycorrhizal fungi in maize (Zea mays L. cv. IAC Taiúba), peanut (Arachis hypogaea L. cv. Tatú) and sorghum [Sorghum bicolor (L.) Moench cv. AG 1017].

Despite the fact that variables related to arbuscular mycorrhizal fungi were not measured in this experiment, a possible negative impact of limestone on arbuscular mycorrhizal fungi association with $U$. decumbens could help to explain the absence of response of herbage mass and tiller population density to liming, as well as the linear decreasing of the tiller weight as liming rates increased during late spring. Thus, contrarily to the hypothesis, the modulation of the morphogenetic and structural traits in $U$. decumbens cv. Basilisk were independent of the liming rates applied, and seem to be strongly linked to the time and intensity in which those responses are triggered at plant level throughout the regrowth process.

Although the effect of defoliation on growth of individual plants has been studied extensively, the magnitude and generality of the responses have been under a great deal of discussion (Ferraro \& Oesterheld 2002). While the sward growth dynamics and its response patterns to frequency and severity of defoliation have been well described for tufted tropical grasses, the responses observed in this experiment indicate particularities in the growth processes at tiller level, which affected the sward recovering in $U$. decumbens.

The leaf elongation rates varied with the regrowth phase $(p<0.0001)$, liming rates $(\mathrm{p}<0.0001)$ and with the interactions season $\mathrm{x}$ defoliation severities $(p=0.0185)$ and regrowth phase $x$ defoliation severities $x$ season $(p=0.0013)$. Despite the significant effect of liming rates on leaf elongation rates, the linear regression equation was not statistically significant. For both defoliation severities during late spring and summer, leaf elongation rates followed a cubic pattern of variation 
along regrowth, increasing during the first phases of regrowth and then decreasing around 10 to 15 days, and again during the last phase of regrowth (Figure 3).

The leaf appearance rate varied with the regrowth phase $(\mathrm{p}=0.0028)$ and with the interaction regrowth phase $\mathrm{x}$ defoliation severities $\mathrm{x}$ season of the year $(\mathrm{p}=0.0006)$. The leaf appearance rate decreased linearly as liming rates increased in R60 during late spring and R40 during summer (Figure 4). The linear and polynomial regression equations were not able to fit the variation of the leaf appearance rate in R40 during late spring and in R60 during summer.

The main process taking place during early regrowth is related to the restoration of the photosynthetic surface through the development of leaf structures (Pereira et al. 2014). In tufted grasses, similarly to the patterns observed in this experiment, emerging leaves are quickly exposed to light immediately after defoliation, through the maintainance of high leaf appearance and leaf elongation rates (Rodolfo et al. 2015, Gastal \& Lemaire 2015). At this phase of regrowth, senescence rates are low (Cruz \& Boval 2000). Besides, in most tropical perennial grasses, the appearance of new tillers may also contribute to the restoration of leaf area during the initial phases of regrowth (Pereira et al. 2014, Rodolfo et al. 2015).

The literature reports that the time required to recover the new leaf area is longer as defoliation severity increases (Ferraro \& Oesterheld 2002, Silva et al. 2015), what was verified in this experiment only during summer. The similar herbage mass at the post-harvest stage probably favored a fast recovering during late spring, even when swards were subjected to severe defoliation. Ferraro \& Oesterheld (2002) showed that the proportion of tissues removed by defoliation had little impact on the canopy responses of several tropical and temperate grasses at the final phases of regrowth. Silva et al. (2015) pointed out that grazing severities equivalent to a removal of $40-60 \%$ of the pre-grazing height are within the limits of grazing resistance and use of tropical perennial grasses, if associated with an adequate frequency of defoliation. This is in accordance with the results of this experiment, since the swards reached the preharvest condition in a similar leaf area index (data not shown) and herbage mass, regardless of the defoliation severities.

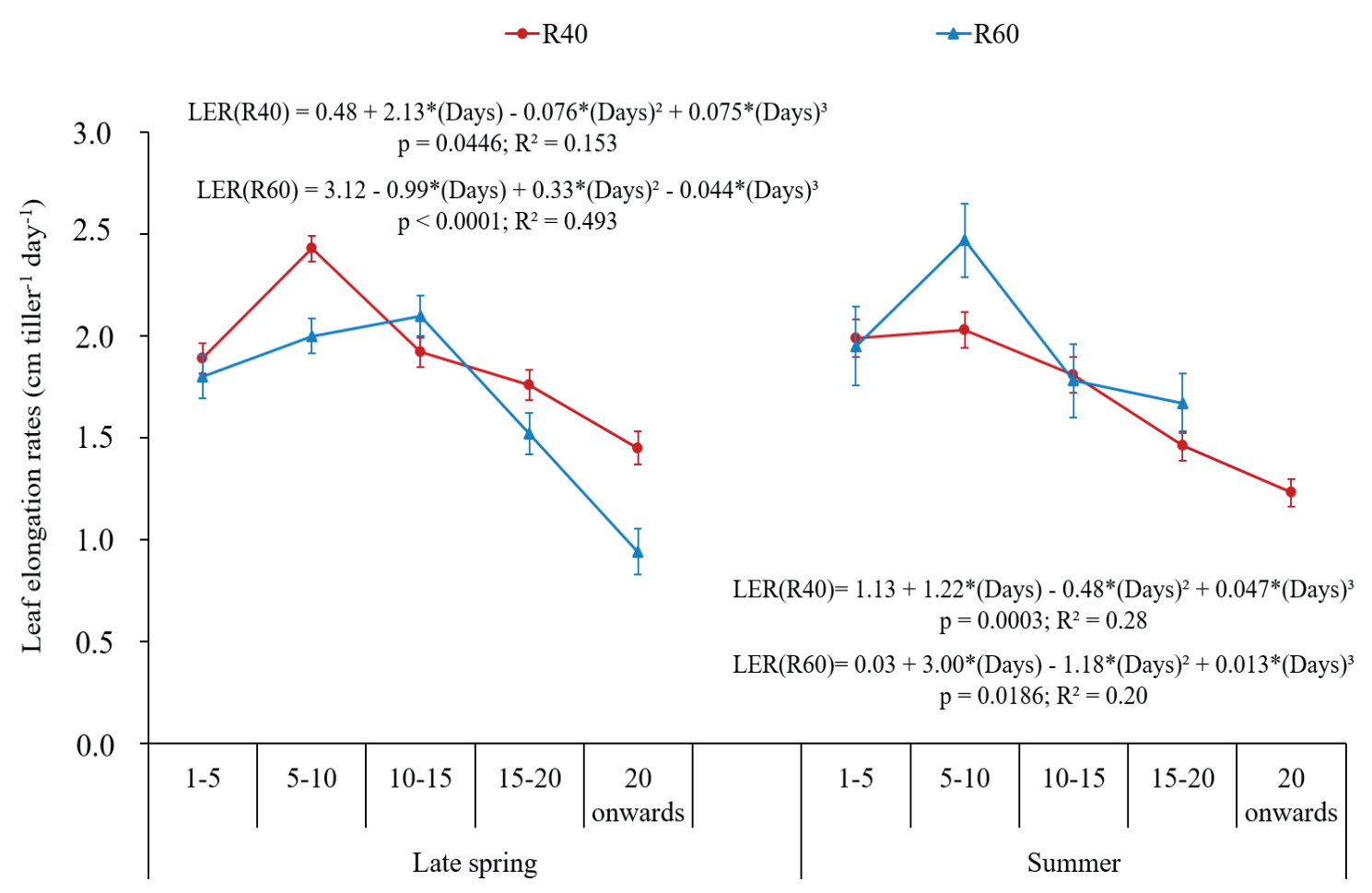

Figure 3. Leaf elongation rates (LER) according to the interaction regrowth phase $\mathrm{x}$ defoliation severities $\mathrm{x}$ season of the year, in Urochloa decumbens cv. Basilisk pastures. 


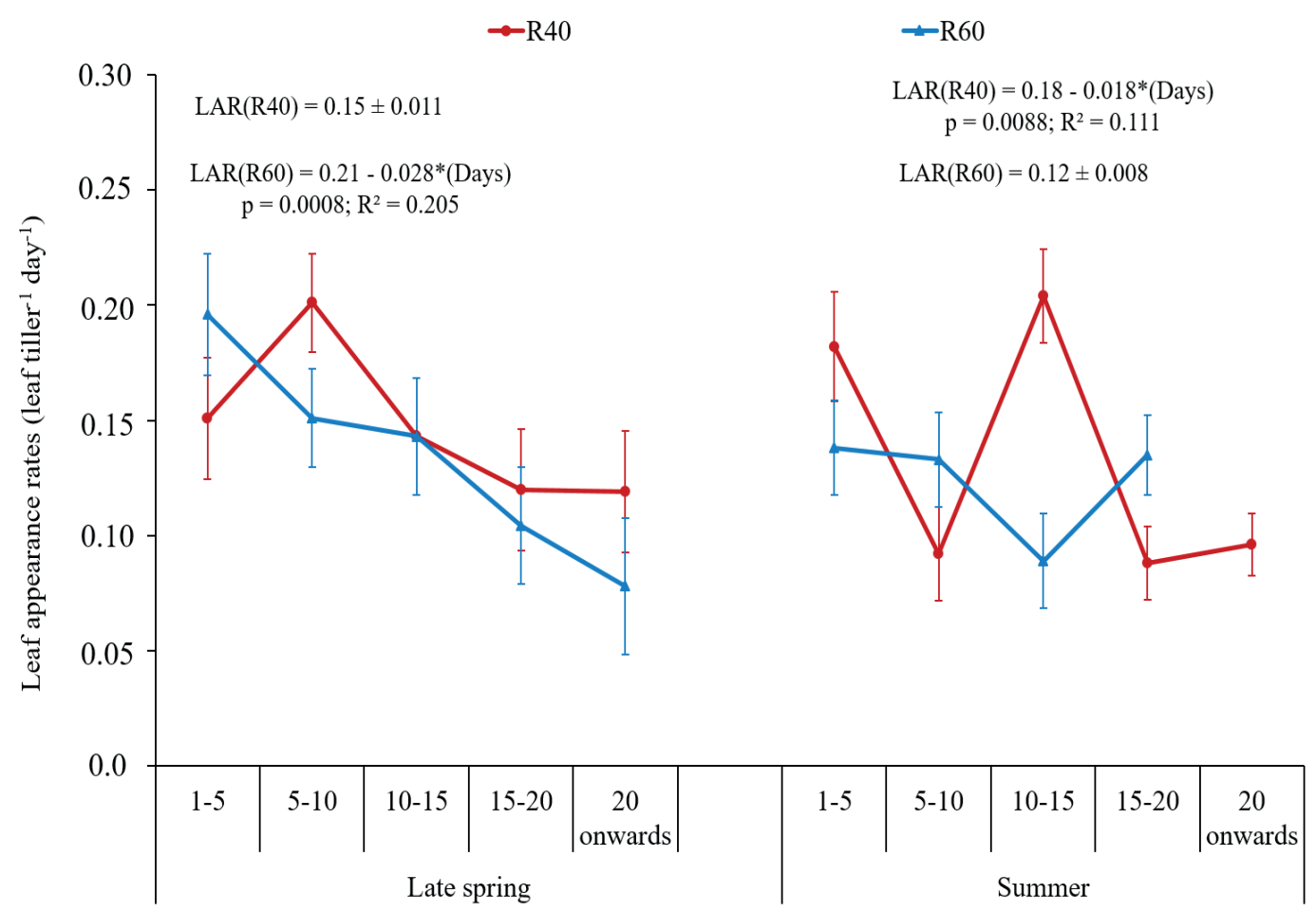

Figure 4. Leaf appearance rates (LAR) according to the interaction regrowth phase $\mathrm{x}$ defoliation severities $\mathrm{x}$ season of the year, in Urochloa decumbens cv. Basilisk pastures.

As the regrowth progresses, the light competition within the canopy increases and plants change their growth pattern as a mean of optimising light capturing (Silva et al. 2015). For most tropical tufted grasses subjected to lenient and/or longer grazing intervals in rotational stocking, stem elongation generally takes place at the final phase of regrowth (Pereira et al. 2014, Rodolfo et al. 2015), even during the vegetative growth stage (Silva et al. 2015). The light availability seems to be the environmental factor controlling stem elongation, what makes the frequency of defoliation the main modulator of plant responses (Silva et al. 2015). Thus, for tufted tropical perennial grasses, the time to interrupt the regrowth has been defined as the moment when their canopies are intercepting around 0.95 of the incoming photosynthetically active solar radiation $\left(\mathrm{LI}_{0.95}\right)$. In this experiment, stem elongation and leaf senescence rates increased and leaf elongation rates decreased from 15 days of regrowth onwards, in both seasons, regardless of liming rates or defoliation severities (Figures 3 and 5).

The stem elogation and leaf senescence rates varied with the regrowth phase $(\mathrm{p}<0.0001$ for both variables) and season $(p=0.0459$ and $p=0.0278$, respectively). For both variables, average values were higher during summer $(0.50 \pm 0.081$ for stem elongation rate and $0.68 \pm 0.106$ for leaf senescence rate) than late spring $(0.38 \pm 0.037$ for stem elongation rate and $0.54 \pm 0.045$ for leaf senescence rate). The stem elongation rate linearly increased as the regrowth progressed. Meanwhile, the leaf senescence rate followed a quadratic pattern (Figure 5). The lowest values for stem elongation and leaf senescence were registered at the initial phases of regrowth, and increased from 15 days of regrowth onwards. The stem elongation and leaf senescence rates increased aproximately $23.6 \%$ and $126 \%$, respectively from the period comprised between 15 and 20 days after harvest to the last phase of regrowth (20 days onwards).

One possible reason for this pattern is related to the morphological changes due to the entrance in the reproductive period of the species, which occurs during summer (Pedreira et al. 2017). Another possible explanation is related to the morphogenetic type expressed by $U$. decumbens. According to Cruz \& Boval (2000), different morphogenetic types may be recognized by particularities in ontogenetic factors controlling the intensity and time for the expression of morphogenetic traits along regrowth 


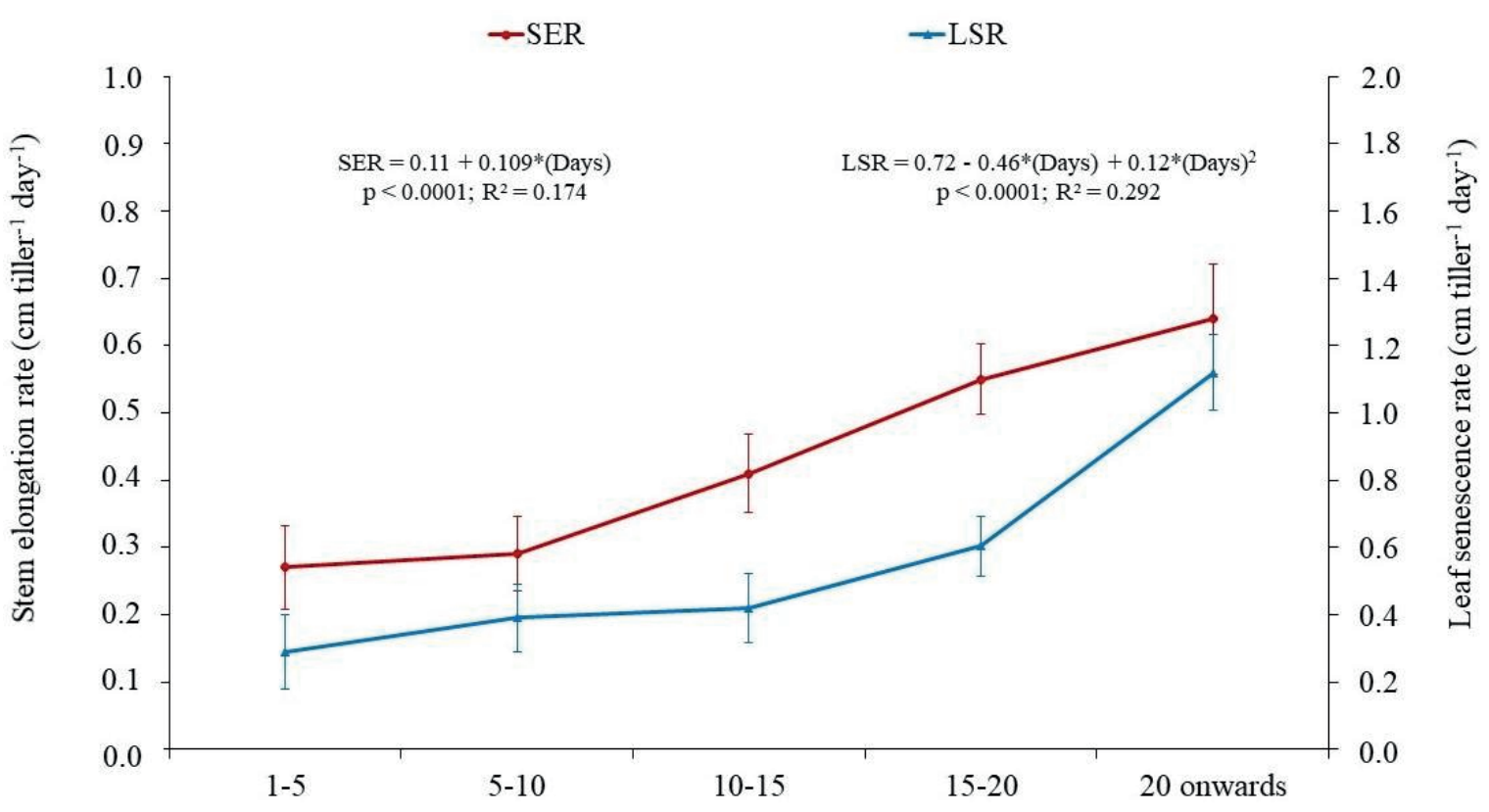

Regrowth phases (Days)

Figure 5. Relationship between stem elongation (SER, circles) and leaf senescence (LSR, triangles) rates of U. decumbens cv. Basilisk along the regrowth, during late spring and summer. Bars represent the standard error of the means.

and their responses to grazing management. In vegetative stoloniferous plants, leaves and stems (stolons) are produced as aerial organs, and the stem elongation rate needs to be considered during the overall regrowth process of these plants (Cruz \& Boval 2000). This occurs because stem elongation is triggered earlier during regrowth in some stoloniferous species (Cruz \& Boval 2000, Alderman et al. 2011), if compared to tufted grasses (Pereira et al. 2014, Rodolfo et al. 2015). Urochloa decumbens is not a strictly stoloniferous species, being classified as a decumbent growth habit grass species. Stems in erect species, as well as the stolons in stoloniferous plants, are called 'spacers'. According to Huber et al. (1998), the spacer plasticity (vertically or horizontally oriented internodes) depends primarily on its function for the plant. Hence, stems on erect plants have normally a higher plasticity to a vertical orientation, while a high level of horizontal morphological plasticity is expected from the stems on stoloniferous plants (Huber et al. 1998, Kroons \& Hutchings 1995).

Thus, even if the frequency of defoliation had been defined by the $\mathrm{LI}_{0.95}$ criterion, the stem elongation at the later phases of regrowth was not controlled in $U$. decumbens swards, indicating that this process was triggered earlier during regrowth
(Figure 5). In the conditions of this experiment, low stem elongation and leaf senescence rates, associated with the maintenance of higher leaf elongation rates, could be reached by the adoption of shorter regrowth intervals, which were up to 20 days, regardless of liming rates or defoliation severities. However, the impacts of shorter grazing intervals to the growth rates and the possible effects to the persistency of the plant community in the long-term need to be further evaluated.

\section{CONCLUSIONS}

1. Increased liming rates do not result in benefits to herbage mass, tiller population density or faster sward recovering;

2. Tiller weight decreases, while the duration of regrowth linearly increases, as liming rates increase, particularly during late spring;

3. Increased stem elongation and senescence rates and decreased leaf elongation rates occur from 15 days of regrowth onwards, regardless of liming rates or defoliation severities;

4. Post-harvest heights ranging $40-60 \%$ of the preharvest height showed to be within the limits of resistence of the species to defoliation; 
5. Liming rates up to $1.0 \mathrm{tha}^{-1}$ have only marginal impacts on the morphogenetic characteristics of Urochloa decumbens cv. Basilisk.

\section{REFERENCES}

AERTS, R. Interspecific competition in natural plant communities: mechanisms, trade-offs, and plant-soil feedbacks. Journal of Experimental Botany, v. 50, n. 330, p. 29-37, 1999.

ALDERMAN, P. D.; BOOTE, K. J.; SOLLENBERGER, L. E. Regrowth dynamics of 'Tifton 85 ' bermudagrass as affected by nitrogen fertilization. Crop Science, v. 51, n. 4, p. 1716-1726, 2011.

CARRENHO, R. et al. The effect of different soil properties on arbuscular mycorrhizal colonization of peanuts, sorghum and maize. Acta Botanica Brasilica, v. 21, n. 3, p. 723-730, 2007.

CLARK, R. B.; ZETO, S. K. Mineral acquisition by arbuscular mycorrhizal plants. Journal of Plant Nutrition, v. 23, n. 7 , p. $867-902,2000$.

COSTA, N. L. et al. Resposta de Brachiaria brizantha cv. Xaraés a níveis de calagem. Pubvet, v. 6, n. 13, p. 1-10, 2012.

CRUZ, P.; BOVAL, M. Effect of nitrogen on some morphogenetic traits of temperate and tropical perennial forage grasses. In: LEMAIRE, G. et al. Grassland ecophysiology and grazing ecology. Wallingford: $\mathrm{CAB}$ International, 2000. p. 151-168.

DIAS-FILHO, M. B. Diagnóstico das pastagens no Brasil. Belém: Embrapa Amazônia Oriental, 2014.

EMPRESA BRASILEIRA DE PESQUISA AGROPECUÁRIA (Embrapa). The Brazilian soil type definition system. Rio de Janeiro: Centro Nacional de Pesquisa de Solos, 2013.

FERRARO, D. O.; OESTERHELD, M. Effect of defoliation on grass growth: a quantitative review. Oikos, v. 98, n. 1, p. 125-133, 2002.

GASTAL, F.; LEMAIRE, G. Defoliation, shoot plasticity, sward structure and herbage utilization in pasture: review of the underlying ecophysiological processes. Agriculture, v. 5, n. 4, p. 1146-1171, 2015.

GEORGE, E.; MARSCHNER, H.; JAKOBSEN, I. Role of arbuscular mycorrhizal fungi in uptake of phosphorus and nitrogen from soil. Critical Reviews in Biotechnology, v. 15 , n. 3-4, p. 257-270, 1995.

GOULDING, K. W. T. Soil acidification and the importance of liming agricultural soils with particular reference to the
United Kingdom. Soil Use and Management, v. 32, n. 3, p. 390-399, 2016.

HUBER, H.; FIJAN, A.; DURING, H. J. A comparative study of spacer plasticity in erect and stoloniferous herbs. Oikos, v. 81, n. 3, p. 576-586, 1998.

KENWARD, M. G.; ROGER, J. H. Small sample inference for fixed effects from restricted maximum likelihood. Biometrics, v. 53, n. 3, p. 983-997, 1997.

KROONS, H. de; HUTCHINGS, M. J. Morphological plasticity in clonal plants: the foraging concept reconsidered. Journal of Ecology, v. 83, n. 1, p. 143-152, 1995.

MAGAlHÃES, A. C. M. et al. Performance of the Brachiaria hybrid 'Mulatto II' under different doses and forms of limestone application in the Amazon. African Journal of Agricultural Research, v. 1, n. 43, p. 31373143, 2017.

MOTTA, P. E. F. et al. Urochloa decumbens growth and $\mathrm{P}$ uptake as affected by long-term phosphate fertilization, mycorrhizal inoculation and historical land use in contrasting Oxisols of the Brazilian Cerrado. Ciência e Agrotecnologia, v. 41, n. 2, p. 209-219, 2017.

OLIVEIRA, P. P. A. et al. Liming and fertilization to restore degraded Brachiaria decumbens pastures grown on an Entisol. Scientia Agricola, v. 60, n. 1, p. 125-131, 2003.

PEDREIRA, C. G. S.; BRAGA, G. J.; PORTELA, J. N. Herbage accumulation, plant-part composition and nutritive value on grazed signal grass (Brachiaria decumbens) pastures in response to stubble height and rest period based on canopy light interception. Crop and Pasture Science, v. 68, n. 1, p. 62-73, 2017.

PEREIRA, L. E. T. et al. Components of herbage accumulation in elephant grass cvar Napier subjected to strategies of intermittent stocking management. Journal of Agricultural Science, v. 152, n. 6, p. 954-966, 2014.

PORTELA, J. N.; PEDREIRA, C. G. S.; BRAGA, G. J. Demografia e densidade de perfilhos de capim-braquiária sob pastejo em lotação intermitente. Pesquisa Agropecuária Brasileira, v. 46, n. 3, p. 315-322, 2011.

PREMAZZI, L. M.; MATTOS, H. B. Percent base saturation as a liming recommendation criteria for two tropical grasses. Boletim da Indústria Animal, v. 59, n. 2, p. 125-136, 2002.

RAIJ, B. V. et al. Recommendations for fertilization and liming to the São Paulo state. Campinas: Instituto Agronômico/Fundação IAC, 1997. (Boletim técnico, 100).

RODOLFO, G. R. et al. Levels of defoliation and regrowth dynamics in elephant grass swards. Ciência Rural, v. 45, n. 7, p. 1299-1304, 2015. 
SILVA, S. C. da; SBRISSIA, A. F.; PEREIRA, L. E. $\mathrm{T}$. Ecophysiology of $\mathrm{C} 4$ forage grasses: understanding plant growth for optimising their use and management. Agriculture, v. 5, n. 3, p. 598-625, 2015.

SIQUEIRA, J. O. et al. The relationship between vesiculararbuscular mycorrhiza and lime: associated effects on the growth and nutrition of brachiaria grass (Brachiaria decumbens). Biology and Fertility of Soils, v. 10, n. 1, p. $65-71,1990$.
VALLE, C. B. et al. Brachiaria genus. In: FONSECA, D. M.; MARTUSCELLO, J. A. Forage plants. Viçosa: Ed. UFV, 2010. p. 30-77.

WERNER, J. C.; PAULINO, V. T.; CANTARELLA, H. Recommendations for fertilization and liming to forage species. In: VAN RAIJ, B.; SILVA, N. M.; BATAGLIA, O. C. Recommendations for fertilization and liming to the São Paulo state. Campinas: Instituto Agronômico/ Fundação IAC, 1996. p. 263-271. (Boletim técnico, 100). 